\title{
Pemberdayaan Masyarakat Pesantren Ar-Rahmah, Rejang Lebong dalam Memanfaatkan Lahan Pekarangan dengan Budi Daya Bawang Merah
}

\section{(Community Empowerment of the Ar-Rahmah Pesantren, Rejang Lebong to Utilize Land with Shallot Cultivation)}

\author{
Marlin Marlin ${ }^{1}$, Antoni Sitorus², Muhamad Solihin ${ }^{3}$, Atra Romeida1 ${ }^{1}$, Reny Herawati ${ }^{1}$ \\ ${ }^{1}$ Program Studi Agroekoteknologi, Fakultas Pertanian, Universitas Bengkulu \\ Jl. WR. Supratman, Kandang Limun, Bengkulu 38371. \\ 2 Program Studi Ekonomi Pembangunan, Fakultas Ekonomi, Universitas Bengkulu \\ Jl. WR. Supratman, Kandang Limun, Bengkulu 38371. \\ ${ }^{3}$ Balai Pelatihan Pertanian Merigi, Desa Batu Ampar, Kecamatan Merigi, Kabupaten Kepahiang, Bengkulu \\ *Penulis Korespondensi: marlin@unib.ac.id \\ Diterima Agustus 2019/Disetujui Desember 2019
}

\begin{abstract}
ABSTRAK
Upaya pemberdayaan masyarakat di lingkungan pesantren Ar-Rahmah di Desa Air Meles Atas, Kabupaten Rejang Lebong, Bengkulu dilakukan bertujuan untuk meningkatkan pendapatan pesantren guna membiayai peserta didik yang kurang mampu dan sekaligus meningkatkan kemampuan pesantren dalam melaksanakan kegiatan pendidikan dan pengajaran. Kegiatan pengabdian kepada masyarakat yang dilakukan berupa kegiatan pendampingan kegiatan usaha budi daya bawang merah di lahan pekarangan Pesantren Ar-Rahmah. Pendampingan dilakukan selama 4 bulan, mulai dari tahap pengkondisian pengelola, guru, siswa dan petani di sekitar pesantren, pemilihan benih, persiapan lahan, penanaman, pemeliharaan, panen, dan pascapanen. Hasil evaluasi terhadap kegiatan menunjukkan bahwa partisipasi dan keterlibatan warga pesantren yang cukup tinggi dalam kegiatan pendampingan budi daya bawang merah. Partisipasi tertinggi adalah saat melakukan pemilihan benih (73\%) dan penanaman (100\%), dan partisipasi rendah pada saat kegiatan pemeliharaan (27\%). Hasil evaluasi menunjukkan tingkat kepuasan peserta $(90-100 \%)$ terhadap pelaksanaan kegiatan pendampingan yang dilakukan. Hasil panen yang diperoleh dapat dimanfaatkan warga pesantren untuk menambah pendapatan pesantren yang dapat digunakan membantu biaya pendidikan dan kemajuan pesantren. Peran serta seluruh masyarakat harus didorong agar keberhasilan pemberdayaan dapat dirasakan seluruh masyarakat. Kegiatan pemberdayaan masyarakat sangat perlu dilakukan secara kontinu untuk meningkatkan kemandirian dan kesejahteraan masyarakat.
\end{abstract}

Kata kunci: budi daya bawang merah, kesejahteraan masyarakat, pemberdayaan masyarakat, pesantren

\begin{abstract}
The community empowerment in the area of Ar-Rahmah pesantren, Air Meles Atas Village, Rejang Lebong Regency, Bengkulu was intended to increase the income of pesantren to finance poor students, and at the same time to enhance the ability of pesantren in carrying out educational and teaching activities. Community service activities carried out in the form of assistance activities in shallot cultivation in the yard of the Ar-Rahmah Pesantren. The assistance program is carried out for 4 months, with such stage of activities as: the preparation stage for managers, teachers, students and farmers around the pesantren, seed selection, land preparation, planting, maintenance, harvesting, and post-harvest. The evaluation result showed that the community participation and involvement in the shallot cultivation assisting program were considered high. The highest participation rates were during the selection of seed activity (73\%) and planting activity (100\%). Meanwhile, the lowest participation rate was during maintenance activities (27\%). The evaluation results showed the level of participants' satisfaction is high (90-100\%) on the implementation of assistance activities. The harvested shallots could increase the income of the boarding school which can be used to help the education cost and education progress of the boarding school. The participation of the entire community would be encouraged so that the success of empowerment program could be felt by the entire community. The community empowerment program need to be carried out continuously, so it would enhance the welfare of and self-sufficiency of the community.
\end{abstract}

Keywords: community empowerment, community welfare, Islamic Boarding School, shallot cultivation 


\section{PENDAHULUAN}

Program pemberdayaan masyarakat di Indonesia dilakukan melalui berbagai kegiatan pengentasan kemiskinan yang dilaksanakan pada beberapa kementerian dan lembaga. Pemberdayaan masyarakat mengedepankan pada pemenuhan kebutuhan masyarakat guna meningkatkan kesejahteraan dan kemandirian dalam masyarakat. Kegiatan pemberdayaan ditujukan pada pendekatan ke arah pembangunan yang lebih berpihak kepada rakyat (Karsidi 2007). Menurut Silkhondze (1999), pemberdayaan masyarakat harus ditujukan untuk membantu masyarakat agar mampu mengembangkan diri dengan inovasi-inovasi yang ada. Pada hakikatnya pemberdayaan adalah suatu proses dan upaya untuk memeroleh atau memberikan daya, kekuatan atau kemampuan kepada individu dan masyarakat lemah agar dapat mengidentifikasi, menganalisis, menetapkan kebutuhan, dan potensi serta masalah yang dihadapi dan sekaligus memilih alternatif pemecahannya dengan mengoptimalkan sumber daya dan potensi yang dimiliki secara mandiri (Widjajanti 2011). Kegiatan pemberdayaan masyarakat harus mampu mengembangkan teknikteknik pendidikan tertentu yang imajinatif untuk menggugah kesadaran masyarakat (Karsidi 2002). Program pemberdayaan masyarakat yang dilakukan harus berorientasi pada kebutuhan masyarakat sasaran, sehingga dapat meningkatkan kemampuan sosial ekonomi masyarakat. Hal ini dapat dilakukan melalui pengembangan sumber daya ekonomi yang ada dalam masyarakat, seperti pemanfaatan lahan untuk kegiatan budi daya tanaman. Pemanfaatan lahan yang tepat akan dapat digunakan untuk memenuhi kebutuhan sehari-hari serta dapat menjadi sumber pendapatan yang bermanfaat.

Budi daya tanaman bawang merah merupakan salah satu kegiatan yang dapat memberi nilai ekonomi yang cukup tinggi bagi pendapatan masyarakat. Bawang merah dapat diusahakan petani di dataran rendah maupun di dataran tinggi. Umumnya bawang merah dibudidayakan di daerah dataran rendah yang beriklim kering dengan suhu agak panas dan cuaca cerah. Provinsi Bengkulu mempunyai potensi untuk pengembangan bawang merah karena memiliki agroklimat yang sesuai untuk budi daya bawang merah, namun pengetahuan tentang teknologi budi daya bawang merah belum dikuasai oleh petani, terutama dalam pemilihan bahan tanam, penggunaan pupuk, serta pengendalian or- ganisme pengganggu tanaman. Perlu upaya transfer ilmu dan teknologi dalam upaya meningkatkan pengembangan bawang merah di daerah-daerah di Indonesia, khususnya di Bengkulu. Penguasaan teknologi tepat guna budi daya bawang merah akan sangat bermanfaat dalam upaya meningkatkan produktivitas bawang merah. Peningkatan minat masyarakat untuk membudidayakan bawang merah harus selalu digalakkan mengingat potensi bawang merah yang memiliki nilai ekonomi tinggi sehingga dapat menjadi sumber pendapatan masyarakat.

Upaya pengembangan bawang merah dapat dilakukan dengan memanfaatkan lahan pekarangan menjadi lahan produktif. Masyarakat sasaran dalam kegiatan ini adalah Pesantren ArRahmah di Desa Air Meles Atas, Kabupaten Rejang Lebong, Provinsi Bengkulu. Pesantren ini memiliki lahan pekarangan \pm 3 ha yang belum dimanfaatkan secara maksimal. Pemanfaatan lahan untuk budi daya bawang merah diharapkan dapat meningkatkan pemanfaatan lahan yang juga akan memberikan pendapatan yang menguntungkan bagi kemajuan pesantren.

Pondok pesantren Ar-Rahmah sejak berdiri tahun 1990 di bawah Yayasan Pendidikan Islam Ar-Rahmah dengan Akta Notaris tahun pada 1990, secara kontinu dan simultan terus melakukan pembenahan dan pengembangan, baik pengembangan yang berbentuk fisik maupun non fisik. Peran serta pesantren terhadap pemberdayaan masyarakat di bidang keilmuan tidak diragukan lagi, terutama dalam menunjang program pemerintah tentang wajib belajar sekolah dasar sembilan tahun, di samping terus melakukan pembinaan keislaman di tengahtengah masyarakat. Peranan Pondok Pesantren dalam hal pembinaan dan pengembangan intelektual dibuktikan dengan diraihnya prestasi beasiswa selama kuliah oleh alumni pondok pesantren Ar-Rahmah tahun 2007 di IAIN Semarang.

Pesantren Ar-Rahmah memiliki siswa yang sebagian besar berasal dari keluarga yang kurang mampu, sehingga memerlukan bantuan peningkatan pendapatan pesantren untuk kelancaran kegiatan pembelajarannya. Pesantren ini memiliki 307 orang santri yang terdiri dari 147 orang laki-laki, dan 160 orang perempuan. Santri-santri ini berasal dari Bengkulu dan beberapa wilayah di Sumatera Selatan. Umumnya, santri-santri ini berasal dari keluarga yang kurang mampu. Hal ini menyebabkan besarnya biaya yang harus dikeluarkan pesantren 
untuk menutupi biaya yang tidak mampu dibayarkan siswanya tersebut. Kondisi ini menyebabkan biaya yang harus ditanggung pesantren menjadi lebih besar untuk pengeluaran kebutuhan pesantren dan pelaksanaan proses belajar mengajar. Padahal pengelola pesantren tidak memiliki usaha lain yang dapat membantu meringankan biaya yang harus dikeluarkan. Dengan demikian, perlu adanyanya upaya pendampingan untuk dapat meningkatkan penghasilan pesantren dengan memanfaatkan potensi yang mereka miliki. Kegiatan pemberdayaan dilakukan dengan melibatkan warga pesantren untuk ikut berpartisipasi dan bekerja sama dalam memanfaatkan lahan pekarangan sebagai sumber penghasilan. Melalui upaya kegiatan ini diharapkan akan dapat membantu meningkatkan pendapatan warga pesantren guna menunjang kegiatan pendidikan dan ekonomi pesantren Ar-Rahmah. Kegiatan ini bertujuan untuk memberdayakan masyarakat desa, khususnya siswa dan tenaga pendidik di Pesantren Ar-Rahmah, Kabupaten Rejang Lebong dengan melakukan transfer pengetahuan dan teknologi budi daya bawang merah. Melalui kegiatan ini diharapkan dapat meningkatkan jiwa wirausaha dan giat bekerja bagi siswa dan tenaga pendidik Pesantren Ar-Rahmah, Kabupaten Rejang Lebong sehingga mereka dapat menjadi warga mandiri.

\section{METODE PELAKSANAAN KEGIATAN}

Kegiatan pendampingan masyarakat dilakukan sejak bulan November 2018-Februari 2019. Kegiatan dilakukan di Pesantren ArRahmah, Desa Air Meles Atas, Kecamatan Selupu Rejang, Kabupaten Rejang Lebong, Provinsi Bengkulu. Kegiatan pengabdian dilakukan dalam beberapa tahap yang meliputi: pengondisian pengelola, guru dan siswa serta petani di sekitar pesantren; persiapan lahan; pemilihan dan persiapan benih; penanaman; pemeliharaan; panen dan pascapanen; serta monitoring dan evaluasi.

\section{Pengondisian Pengelola, Guru, dan Siswa serta Petani di Sekitar Pesantren}

Kegiatan ini perlu dilakukan untuk memetakan kondisi peserta kegiatan pendampingan, untuk kemudian melakukan pendekatan guna memberikan pengetahuan terhadap tujuan kegiatan pendampingan dan manfaat bagi peserta terdampak khususnya warga pesantren.
Pengetahuan ini penting untuk menumbuhkan kesadaran terhadap pentingnya partisipasi warga terdampak kegiatan untuk mencapai keberhasilan program. Selain itu, tahapan ini diperlukan untuk melakukan transfer pengetahuan yang berkaitan dengan budi daya bawang merah yang akan dilaksanakan di tempat mereka.

\section{Persiapan Lahan}

Kegiatan persiapan lahan dilakukan dengan membersihkan lahan dari gulma dan kotoran lainnya, serta dilakukan penggemburan tanah untuk memperbaiki fisik dan tekstur tanah. Selanjutnya, dilakukan pembuatan bedeng tanam dengan lebar $100 \mathrm{~cm}$, tinggi $30 \mathrm{~cm}$, dan jarak antar-bedeng $40 \mathrm{~cm}$. Pemasangan mulsa dilakukan pada masing-masing bedeng dengan menggunakan mulsa plastik hitam perak. Proses pembuatan lubang tanam dilakukan dengan melubangi mulsa dengan jarak tanam $15 \times 20 \mathrm{~cm}$. Pupuk kandang diberikan pada setiap lubang tanam, dengan dosis $100 \mathrm{~g} /$ lubang. Pupuk kandang yang digunakan adalah pupuk kandang yang berasal dari kotoran kambing yang telah disimpan dan dikering anginkan 3 minggu sebelum tanam. Proses penyimpanan dan pengeringan ini dimaksudkan untuk mempercepat proses dekomposisi bahan organik yang terdapat dalam kotoran kambing tersebut.

\section{Pemilihan dan Persiapan Benih}

Benih bawang merah yang digunakan adalah berupa umbi bawang merah. Benih bawang merah diperoleh dari penangkar benih yang berasal dari Brebes, Jawa Timur. Benih selanjutnya dibersihkan dari kulit dan daun kering. Benih dipilih dengan ukuran $\pm 7 \mathrm{~g}$. Perbanyakan dengan menggunakan umbi membutuhkan bahan tanam 1-1,5 ton/ha (Suherman \& Basuki 1990). Sebelum penanaman, dilakukan pemotongan $1 / 3$ bagian ujung umbi dengan menggunakan pisau yang tajam dan bersih. Umbi yang sudah dipotong direndam dengan larutan PGPR (plant growth promotion rhizobacteria) dengan konsentrasi $5 \mathrm{~g} / \mathrm{L}$, selama 15 menit.

\section{Penamaman}

Penamaman benih dilakukan pada lubang tanam yang telah disiapkan dengan menanam 1 umbi per lubang tanam. Penanaman dilakukan dengan bagian potongan menghadap ke atas dengan kedalaman 3-5 $\mathrm{cm}$, kemudian ditutup dengan tanah tipis. 


\section{Pemeliharaan}

Kegiatan pemeliharaan meliputi kegiatan penyiraman, pemupukan, dan pengendalian organisme pengganggu tanaman. Penyiraman dilakukan 1 kali sehari, tergantung dengan kondisi cuaca. Pemupukan dilakukan mulai tanaman berumur 1 MST dengan menggunakan pupuk NPK mutiara dengan dosis $5 \mathrm{~g} / \mathrm{L}$. Pemupukan dilakukan dengan cara melarutkan pupuk sesuai dosis anjuran. Larutan pupuk selanjutnya disiramkan pada tanaman dengan menggunakan gembor. Pengendalian hama ulat bawang dilakukan dengan menggunakan insektisida selektif berbahan aktif abamektin dan spinosad sesuai anjuran, sedangkan untuk mengendalikan serangan penyakit antraknosa yang disebabkan cendawan Colletrotichum sp. digunakan fungisida selektif berbahan aktif difenoconazol (Hilman et al. 2014). Penyemprotan dengan menggunakan knapsack sprayer. Penyemprotan dilakukan pagi atau sore hari saat tidak ada hujan.

\section{Panen dan Pascapanen}

Kegiatan pemanenan dilakukan saat tanaman sudah menunjukkan ciri-ciri seperti pangkal daun telah layu, daun berwarna kuning, umbi telah muncul ke permukaan tanah dan umbi berwarna merah keunguan. Panen dilakukan pada umur sekitar 65 hari setelah tanam. Umbi yang sudah dipanen langsung dikeringanginkan di bawah matahari. Selanjutnya dibuat ikatan dan digantungkan di atas para-para yang terbuat dari bambu.

\section{Monitoring dan Evaluasi}

Khalayak sasaran dalam kegiatan pemberdayaan ini adalah warga pesantren ArRahmah Kabupaten Rejang Lebong yang berjumlah 60 orang, terdiri atas siswa (45 orang), guru dan staf (7 orang), dan petani sekitar pesantren (8 orang). Sasaran merupakan masyarakat yang dipilih dan dianggap berpatisipasi aktif dalam kegiatan pemberdayaan masyarakat Pesantren Ar-Rahmah. Jumlah sampel dalam kegiatan ini bejumlah 30 orang (Tabel 1). Monitoring dan evaluasi dilakukan untuk menentukan tingkat partisipasi masyarakat, tingkat kepuasan terhadap pelaksanaan kegiatan, tingkat kepuasan terhadap ketersediaan sarana (alat dan bahan), tingkat kepuasan terhadap kegiatan panen dan pascapanen, dan dampak kegiatan terhadap masyarakat sasaran.

Metode pengumpulan data yang digunakan adalah analisis deskriptif yang ditujukan untuk
Tabel 1 Sebaran responden pada kegiatan pemberdayaan masyarakat di Pesantren Ar-Rahmah, Kabupaten Rejang Lebong

\begin{tabular}{lc}
\hline \multicolumn{1}{c}{ Responden } & Jumlah (orang) \\
\cline { 1 - 2 } Umur & 3 \\
$<15$ & 19 \\
$15-20$ & 1 \\
$21-30$ & 3 \\
$31-40$ & 3 \\
$41-50$ & 1 \\
$>50$ & \\
\hline Pendidikan & 1 \\
S1 & 23 \\
SLTA & 6 \\
SLTP & \\
\hline Jenis Kelamin & 18 \\
\hline Laki-laki & 12 \\
Perempuan & \\
\hline Pekerjaan & 4 \\
Petani & 23 \\
Pelajar & 4 \\
\hline Guru & \\
\hline
\end{tabular}

mengumpulkan informasi mengenai kondisi (status) suatu gejala yang ada. Hal ini dikarenakan tim ingin memeroleh gambaran tentang pelaksanaan pemberdayaan masyarakat di pesantren sasaran. Analisis secara deskriptif diharapkan dapat memberikan penjelasan proses pemberdayaan masyarakat sasaran, yang menggambarkan karakteristik masyarakat tersebut.

\section{HASIL DAN PEMBAHASAN}

Pengembangan sektor ekonomi strategis dalam masyarakat perlu dikembangkan sesuai dengan kondisi dan potensi yang dimiliki daerah. Setiap daerah memiliki potensi sumber daya manusia dan sumber daya alam yang spesifik dan berbeda. Masyarakat sasaran pemberdayaan adalah Pesantren Ar-Rahmah terletak di daerah pegunungan sekitar $900 \mathrm{mdpl}$. Pesantren ArRahmah memiliki lahan pekarangan yang luas \pm 3 ha, yang merupakan lahan yang strategis untuk pengembangan budi daya tanaman hortikultura, khususnya bawang merah sebagai komoditas hortikultura unggulan dengan nilai ekonomi yang cukup tinggi. Pemanfaatan lahan pesantren yang luas untuk budi daya bawang merah memiliki potensi yang sangat besar untuk menghasilkan keuntungan. Potensi wilayah yang strategis serta didukung oleh tersedianya tenaga kerja muda yang produktif merupakan modal utama untuk 
meningkatkan kesejahteraan masyarakat di Pesantren Ar-Rahmah.

Upaya pemberdayaan masyarakat di Pesantren Ar-Rahmah melibatkan semua warga pesantren yang terdiri dari guru, murid, serta petani sekitar yang berdomisili di sekitar pesantren. Keterlibatan masyarakat pesantren dalam kegiatan seperti disajikan dalam Gambar 1 dan 2. Keterlibatan masyarakat tertinggi terjadi pada saat pelaksanaan penanaman $(100 \%)$. Pada proses penanaman, semua warga pesantren terlibat dalam kegiatan tersebut. Mereka dibagi menjadi 4 kelompok, masing-masing kelompok dipimpin oleh satu orang guru dan petani pendamping. Setiap kelompok mengelola satu luasan lahan $\pm 1000-1500 \mathrm{~m}^{2}$. Keterlibatan masyarakat yang terendah adalah dalam proses pemeliharaan tanaman. Hal ini disebabkan karena, periode kegiatan dilakukan menjelang masa ujian anak-anak di pesantren. Pada

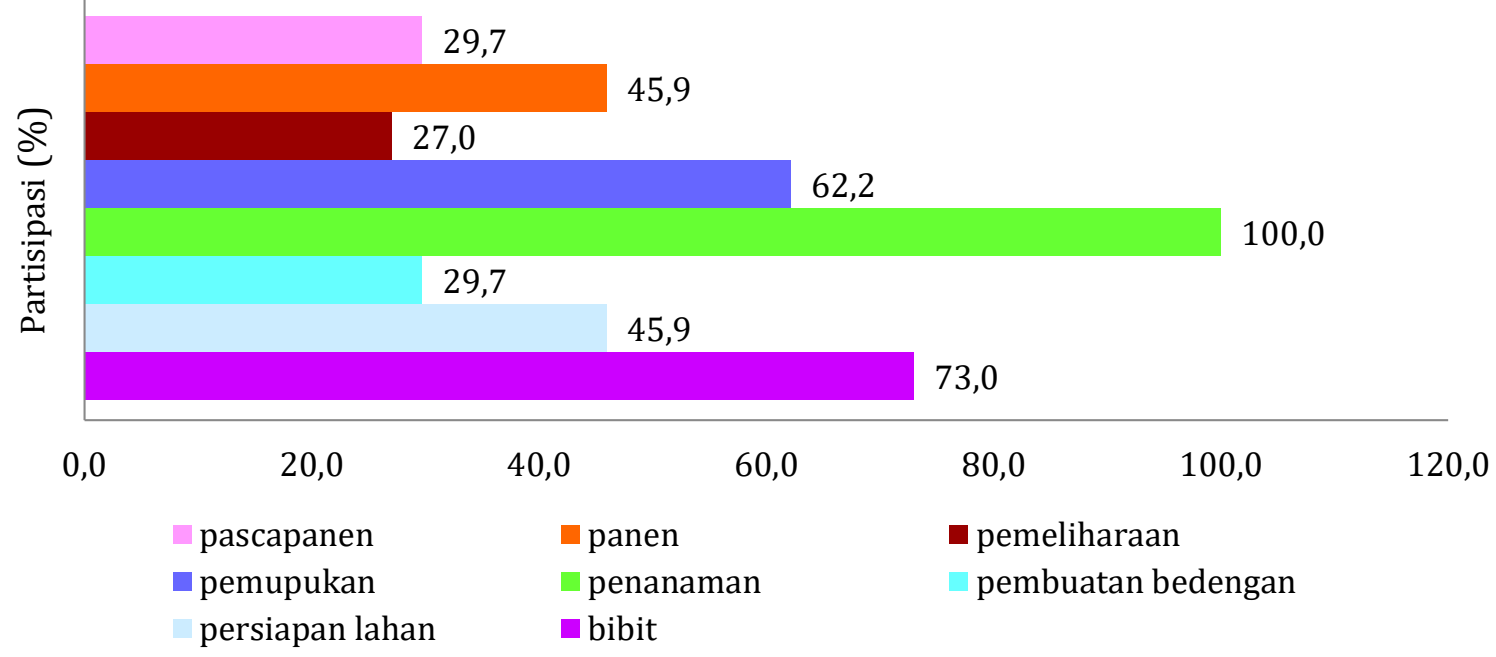

Gambar 1 Tingkat partisipasi masyarakat dalam kegiatan budi daya bawang merah di Pesantren Ar-Rahmah Kabupaten Rejang Lebong.

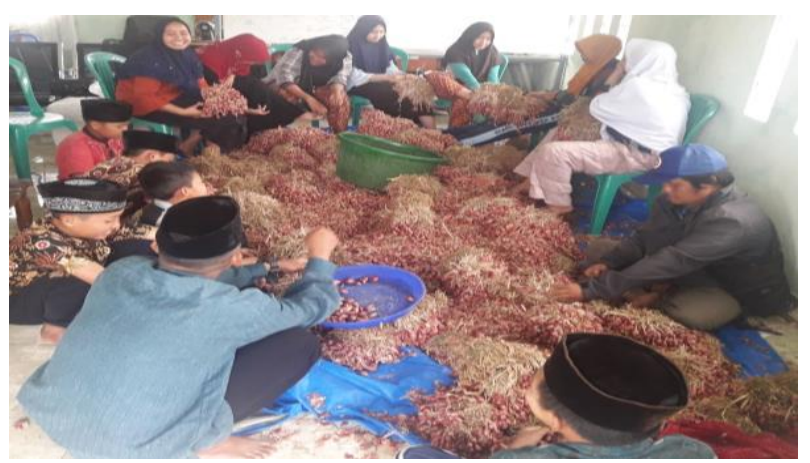

a

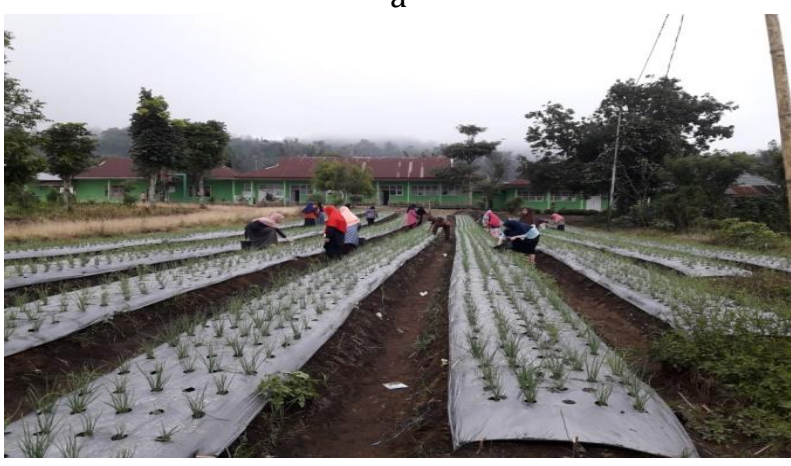

C

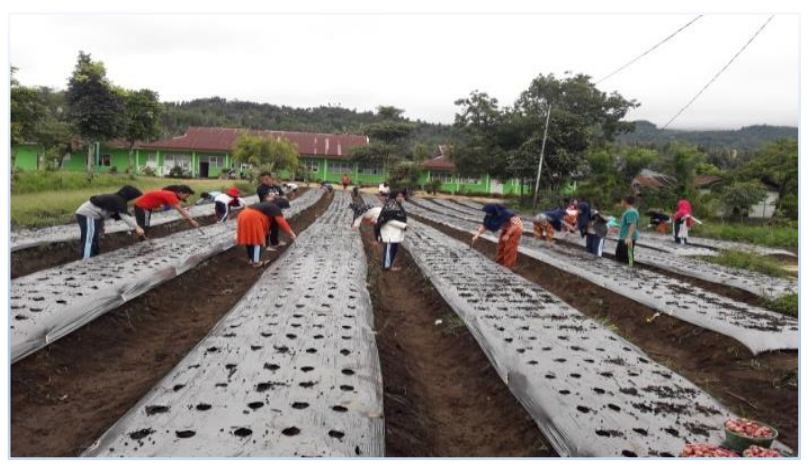

b

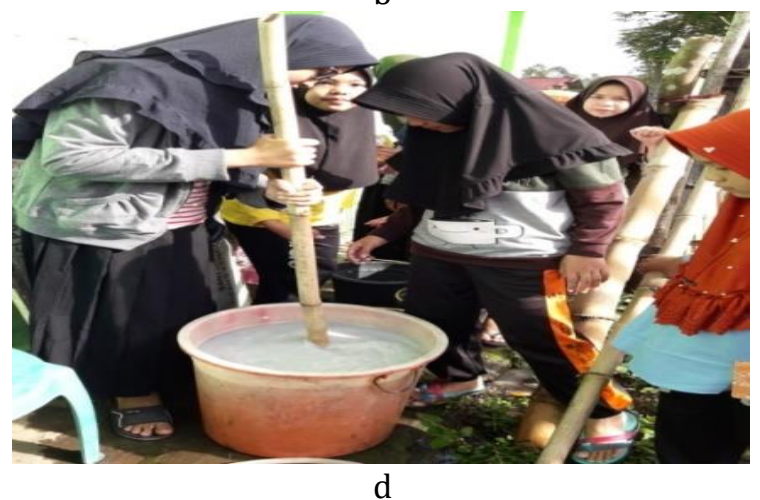

Gambar 2 Partisipasi masyarakat dalam kegiatan budi daya bawang merah di Pesantren Ar-Rahmah Kabupaten Rejang Lebong; a) Kegiatan persiapan benih, b) Kegiatan penanaman bawang merah, c) Kegiatan pemeliharaan, dan d) Pembuatan larutan pupuk. 
kegiatan pemeliharaan santri lebih fokus menyiapkan diri dalam mengadapi ujian akhir semester, sehingga tidak dapat terlibat jauh dalam proses pemeliharaan tanaman.

Hasil evaluasi terhadap materi teknologi budi daya bawang merah yang diberikan terhadap masyarakat pesantren Ar-Rahmah menunjukkan adanya kepuasan dari masyarakat (90-100\%) terhadap materi yang disampaikan. (Tabel 2). Antusiasme yang tinggi ditunjukkan dengan kehadiran mereka dalam setiap tahap kegiatan yang dilakukan. Selain itu, mereka juga merasakan puas dan sangat puas terhadap kemudahan materi dan pelaksanaan kegiatan pendampingan yang dilakukan. Masyarakat di pesantren Ar-Rahmah sangat merespons semua kegiatan pendampingan dengan baik. Mereka juga cukup terbuka akan inovasi yang diberikan. Masyarakat di pesantren Ar-Rahmah menyadari akan manfaat yang akan diperoleh dari kegiatan pendampingan melalui upaya budi daya bawang merah. Hal yang sama dijelaskan oleh Widjajanti (2011), bahwa untuk dapat meningkatkan keberdayaan masyarakat bukan hanya modal fisik yang harus ditingkatkan, tetapi harus ditingkatkan pula kualitas sumber daya manusianya. Faktor partisipasi dari masyarakat menjadi faktor penting dan dominan yang menentukan keberhasilan program pemberdayaan masyarakat. Adanya kerja sama antara pelaku dan penerima manfaat dari kegiatan pemberdayaan masyarakat dapat mempercepat keberhasilan pelaksanaan kegiatan pemberdayaan sesuai yang diharapkan.

Respons positif juga ditunjukkan masayarakat terhadap penyediaan bahan dan alat selama kegiatan pendampingan penanaman bawang merah. Masyarakat menunjukkan respons puas dan sangat puas terhadap bahan dan alat yang tersedia (Tabel 2). Sejumlah 3,3-13,3\% masyarakat yang menyatakan ketersediaan pupuk, pestisida, dan alat-alat pertanian masih sedikit. Hal ini terjadi karena pada saat pelaksanaan kegiatan beberapa jenis pupuk dan pestisida tersedia dalam jumlah yang sangat terbatas. Ketersediaan sarana dan prasarana diperlukan dalam kelancaran kegiatan budi daya, namun demikian semangat tinggi dari masyarakat peserta kegiatan juga harus ditingkatkan guna kesuksesan kegiatan pemberdayaan masyarakat.

Kegiatan budi daya bawang merah dilakukan mulai dari tahapan persiapan lahan hingga pelaksanaan panen dan pascapanen. Sejak tanam hingga tanaman berumur 6 MST, hujan turun dengan intensitas yang tinggi di daerah Air Meles lokasi pesantren Ar-Rahmah. Hal ini cukup mengkhawatirkan karena adanya curah hujan tinggi pada malam hari akan meninggalkan embun pagi yang selanjutnya dapat menjadi stimulan bagi munculnya serangan cendawan penyebab penyakit busuk daun dan busuk batang. Pencegahan munculnya penyakit tersebut diantisipasi dengan melakukan peyemprotan di pagi hari dengan mengggunakan air untuk menghindari endapan embun pada daun tanaman. Semua kendala tersebut dapat diatasi dengan baik, berkat kesigapan petani dan penyuluh pertanian di lapang dalam mengatasi serangan penyakit busuk daun dan busuk batang bawang merah.

Pada setiap tahap kegiatan diikuti oleh peserta pendampingan. Hal ini terlihat dari respons positif yang ditunjukkan oleh responden (76,7-93,3\%) yang menyatakan setuju hingga sangat setuju atas kepuasan terhadap pelaksanaan kegiatan budi daya bawang merah (Gambar 3). Adanya partisipasi yang tinggi dari masyarakat sangat mendukung keberhasilan kegiatan pemberdayaan masyarakat yang dilakukan di pesantren Ar-Rahmah. Hasil penelitian menunjukkan adanya respons kepuasan yang tinggi dari peserta kegiatan pendampingan (Gambar 4).

Hasil ini menunjukkan bahwa masayarakat menyadari pentingnya kegiatan pemberdayaan yang dilakukan dengan ikut serta secara aktif

Tabel 2 Hasil evaluasi tingkat kepuasan partisipan terhadap pelaksanaan kegiatan pendampingan di pesantren Ar-Rahmah Kabupaten Rejang Lebong, Provinsi Bengkulu

\begin{tabular}{lccccc}
\hline \multicolumn{1}{c}{ Aspek penilaian } & $\begin{array}{c}\text { Tidak } \\
\text { tahu (\%) }\end{array}$ & $\begin{array}{c}\text { Tidak } \\
\text { puas (\%) }\end{array}$ & $\begin{array}{c}\text { Agak puas } \\
(\%)\end{array}$ & $\begin{array}{c}\text { Puas } \\
(\%)\end{array}$ & $\begin{array}{c}\text { Sangat } \\
\text { puas (\%) }\end{array}$ \\
\hline Penyampaian materi kegiatan & 0 & 0 & 0,0 & 90,0 & 10,0 \\
Kemudahan materi & 0 & 0 & 6,7 & 63,3 & 30,0 \\
Kegiatan pendampingan & 0 & 0 & 0,0 & 50,0 & 50,0 \\
Ketersediaan bibit & 0 & 0 & 0,0 & 50,0 & 50,0 \\
Ketersediaan pupuk & 0 & 0 & 3,3 & 43,3 & 53,3 \\
Ketersediaan pestisida dan fungisida & 0 & 0 & 6,7 & 53,3 & 40,0 \\
Ketersediaan alat-alat & 0 & 0 & 13,3 & 43,3 & 43,3 \\
\hline
\end{tabular}




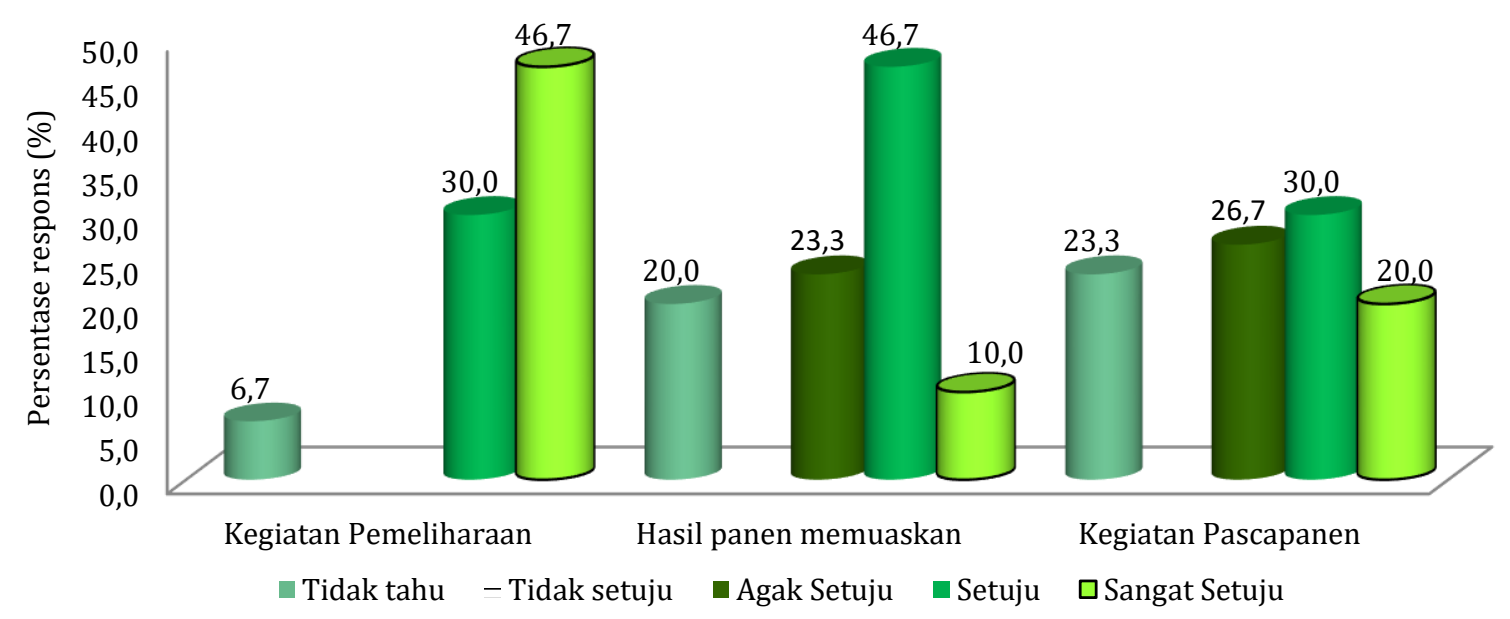

Gambar 3 Respons masyarakat terhadap pelaksanaan tahapan dalam kegiatan budi daya bawang merah di pesantren Ar-Rahmah (panen dan pascapanen).

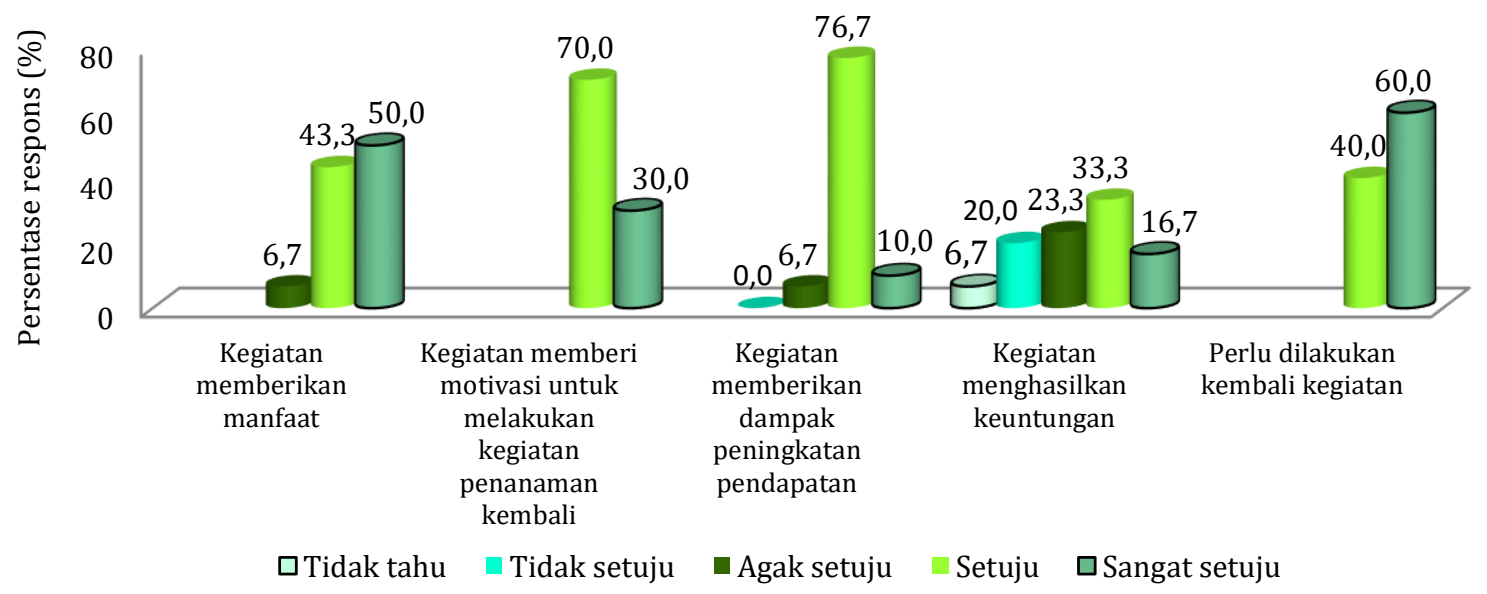

Gambar 4 Respons masyarakat terhadap dampak upaya pemberdayaan masyarakat melalui pemanfaatan lahan pesantren untuk budi daya bawang merah.

dalam setiap tahapan kegiatan. Kegiatan ini juga memberikan dampak positif bagi peningkatan pengetahuan dan keterampilan masyarakat mengenai teknik budi daya bawang merah. Menurut Pretty (1995) terdapat 7 tipologi partisipasi dalam masyara meliputi: 1) Mandiri (self mobilization); 2) Partisipasi interaktif; 3) Partisipasi fungsional; 4) Partisipasi insentif; 5) Partisipasi konsultatif; 6) Partisipasi informatif; dan 7) Partisipasi pasif atau manipulative. Antusiasme masyarakat terhadap kegiatan pemberdayaan ini termasuk dalam tipologi partisispasi fungsional, di mana masyarakat terlibat dalam kegiatan secara berkelompok yang secara bertahap kemudian dapat melaksanakan kegiatan secara mandiri.

Hal ini menunjukkan keberhasilan transfer ilmu dan teknologi yang diberikan. Penguasaan ilmu dan keterampilan ini akan sangat bermanfaat bagi masyarakat sehingga di masa mendatang mereka dapat menerapkan secara mandiri. Sumodiningrat (2000) menjelaskan bahwa keberdayaan masyarakat ditandai adanya kemandirian yang dicapai melalui proses pemberdayaan masyarakat. Selanjutnya, Sulistiyani (2004) menjelaskan lebih rinci bahwa secara etimologis pemberdayaan berasal dari kata dasar "daya" yang berarti kekuatan atau kemampuan. Dengan demikian, kegiatan pemberdayaan masyarakat dapat diartikan sebagai proses untuk memperoleh daya, kekuatan atau kemampuan. Dalam hal ini, pemberdayaan masyarakat ditujukan untuk meningkatkan daya atau kekuatan masyarakat sehingga menjadi masyarakat yang kuat dan mandiri.

Program pemberdayaan masyarakat merupakan upaya mendorong dan melindungi tumbuh dan berkembangnya kekuatan ekonomi lokal dan penguasaan ilmu pengetahuan dan teknologi (iptek) oleh masyarakat yang berbasiskan pada 
kekuatan rakyat (Mahmudi 1999). Terkait dengan kegiatan pemberdayaan masyarakat di pesantren Ar-Rahmah, maka tujuan yang ingin dicapai adalah untuk membentuk masyarakat pesantren yang kuat dan mandiri yang dapat menguasai ilmu pengetahuan dan teknologi. Kemandirian tersebut meliputi kemandirian berpikir, bertindak serta dapat mengatasi permasalahan yang mereka hadapi dengan cara mencari solusi atas permasalahan tersebut. Lebih lanjut dijelaskan oleh Widjajanti (2011) bahwa kemandirian masyarakat merupakan suatu kondisi yang dialami oleh masyarakat yang ditandai dengan kemampuan memikirkan, memutuskan serta melakukan sesuatu yang dipandang tepat demi mencapai pemecahan masalah-masalah yang dihadapi dengan mempergunakan daya kemampuan yang dimiliki.

Menurut Widjajanti (2011), adanya suatu norma atau nilai yang telah dipahami bersama dalam masyarakat dapat memperkuat jaringan sosial/kerja yang positif, terjalinnya kerja sama yang saling menguntungkan, menumbuhkan kepedulian, dan solidaritas yang tinggi serta dapat mendorong tingkat kepercayaan antara sesama dalam rangka tercapainya tujuan bersama. Dengan demikian, maka masyarakat harus mampu bekerja sama dalam meningkatkan kualitas kemandirian dalam mengatasi masalah yang dihadapi (Karsidi 2002).

Pemanfaatan lahan yang dimiliki pesantren dengan budi daya bawang merah merupakan langkah tepat untuk memberdayakan sumber daya alam dan sumber daya manusia di pesantren Ar-Rahmah. Pada penggunaan sebanyak 83 kg bibit bawang merah yang ditanam, menghasilkan panen sebanyak $785 \mathrm{~kg}$ bawang merah. Hasil ini cukup menguntungkan petani dan masyarakat pesantren, karena dari penggunaan bibit $1 \mathrm{~kg}$ umbi akan dapat menghasilkan panen sebesar 9,46 kg umbi bawang merah. Lahan pekarangan yang selama ini tidak dimanfaatkan menjadi lahan produktif yang dapat menambah pendapatan pesantren. Bawang merah merupakan tanaman hortikultura yang dapat dipanen pada umur 2,5 bulan, sehingga memungkinkan dilakukan sebanyak 2-3 kali penanaman dalam satu tahun yang dapat memberikan keuntungan bagi masyarakat pesantren. Potensi lahan yang dikelola dapat menjadi sumber pendapatan yang bermanfaat bagi kesejahteraan pesantren Ar-Rahmah. Peran serta seluruh masyarakat harus didorong agar keberhasilan pemberdayaan dapat dirasakan masyarakat. Hasil dari kegiatan pemberdayaan tidak bisa dilihat dengan segera seperti halnya pembangunan fisik, namun ke depan (sepuluh atau lima belas tahun lagi), tercapainya masyarakat yang mandiri sebagai hasil kegiatan pemberdayaan pada saat ini, akan mampu meningkatkan kesejahteraan masyarakat dan bangsa Indonesia (Karsidi 2007). Penguatan peran serta masyarakat harus didorong seluasluasnya melalui kegiatan pendampingan menuju suatu masyarakat yang mandiri. Disamping itu, perlu pengembangan organisasi, ekonomi jaringan, dan faktor-faktor pendukung lainnya. Dengan usaha pemberdayaan masyarakat diharapkan dapat memberikan manfaat bagi peningkatan kemandirian dan kesejahteraan masyarakat di pesantren Ar-Rahmah.

\section{SIMPULAN}

Upaya pemberdayaan masyarakat pesantren Ar-Rahmah dapat meningkatkan pemanfaatan lahan pesantren dengan budi daya bawang merah. Lahan pesantren yang belum dimanfaatkan dapat menghasilkan sebanyak $785 \mathrm{~kg}$ umbi bawang merah dari $83 \mathrm{~kg}$ umbi bibit (ratio $=1: 9,46)$. Masyarakat berpartisipasi terhadap kegiatan pemberdayaan ini dengan tipologi partisispasi fungsional. Melalui kegiatan pemberdayaan yang dilakukan dapat menumbuhkan jiwa wirausaha dan memotivasi masyarakat untuk giat bekerja secara mandiri sehingga dapat meningkatkan kesejahteraan masyarakat. Upaya pemberdayaan masyarakat menimbulkan semangat dan jiwa kemandirian untuk memanfaatkan sumber daya yang dimiliki secara optimal. Perlu komitmen yang kuat dan upaya yang sungguh-sungguh agar keberhasilan program pemberdayaan masyarakat pesantren dapat terus dilaksanakan, sehingga kesajahteraan masyarakat pesantren dapat diwujudkan. Melalui kegiatan pemberdayaan masyarakat di pesantren Ar-Rahmah diharapkan akan menjadi kegiatan yang bermanfaat bagi warga masyarakat pesantren secara utuh dan berkesinambungan.

\section{UCAPAN TERIMA KASIH}

Ucapan terima kasih disampaikan kepada Bank Indonesia melalui Program corporation social responsibility (CSR) yang telah membantu pendanaan dalam program pendampingan budi daya bawang merah di pesantren Ar-Rahmah Kabupaten Rejang Lebong. 


\section{DAFTAR PUSTAKA}

Hilman Y, Rosliani R, Palupi ER. 2014. Pengaruh ketinggian tempat terhadap pembungaan, produksi, dan mutu benih botani bawang merah. Jurnal Hortikultura. 4(2): 154-161. https://doi.org/10.21082/jhort.v24n2.2014.p 154-161

Karsidi R. 2002. Pemberdayaan masyarakat petani dan nelayan kecil. Semiloka Pemberdayaan Masyarakat di Jawa Tengah dalam Rangka Pelaksanan Otoda, Badan Pemberdayaan Masyarakat Jateng, Semarang (ID) 4-6 Juni 2002.

Karsidi R. 2007. Pemberdayaan masyarakat untuk usaha kecil dan mikro (pengalaman empiris di Wilayah Surakarta Jawa Tengah). Jurnal Penyuluhan. 3(2): 136-145. https:// doi.org/10.25015/penyuluhan.v3i2.2161

Mahmudi A. 1999. Prinsip-Prinsip Pemberdayaan Masyarakat. TOT P2KP oleh LPPSLH, Ambarawa (ID).
Pretty J. 1995. "Regenerative Agriculture: Policies and Practice for Sustainability and Selfreliance". London (EN): Earthscan.

Silkhondze WB. 1999. The role of extension in farmer education and information dissemination in Swaziland. Adult Education and Development, 53.

Suherman R, Basuki RS. 1990. Strategi pengembangan luas areal usaha tani bawang merah (Allium cepa var. ascalonicum) di Jawa Barat: tinjauan dari segi biaya usahatani terendah. Bulletin Penelitian Hortikultura. Edisi khusus XVIII(1): 11-18.

Sulistiyani AT. 2004. Kemitraan dan Model-Model Pemberdayaan. Yogyakarta (ID): Gaya Media.

Sumodiningrat G. 2000. Visi dan Misi Pembangunan Pertanian Berbasis Pemberdayaan. Yogyakarta (ID): IDEA.

Widjajanti K. 2011. Model pemberdayaan masyarakat. Jurnal Ekonomi Pembangunan. 12(1): 15-27. https://doi.org/10.23917/jep. v12i1.202 